\title{
Appendix: Biographies of Jesuit Righteous among the Nations
}

We are pleased to present here the biographies of the fifteen Jesuits who have been identified and honored by Yad Vashem with the title "Righteous among the Nations." For permission to include these in this issue, we wish to thank the staff of Yad Vashem, especially Ms. Irena Steinfeldt and the editors of The Encyclopedia of the Righteous among the Nations (www.yadvashem.org).

\section{Boetto, Father Pietro}

Jesuit Cardinal Pietro Boetto (1871-1946) was the archbishop of Genoa from 1938 to 1946 after many years in leadership positions in the Society of Jesus. Pope Pius XI named him a cardinal in 1935. He has been recognized for saving many Jewish lives while working with the outlawed Jewish rescue network "Delasem." He and his secretary Fr. Francesco Repetto "recruited bishops and archbishops throughout northern Italy to help in this endeavor, thus creating rescue networks that saved hundreds, if not thousands, of Jews [...]. The help included shelter in religious institutions, false documents, hospitalization under false names, and escape to Switzerland."

On November 14, 2016, Yad Vashem honored Cardinal Pietro Boetto as Righteous among the Nations.

\section{Braun, Father Roger}

Roger Braun was a Jesuit priest. During the war, he devoted himself to the saving of persecuted Jews without any attempt to proselytize them. On the contrary, he tried to persuade Jews to adhere to their ancestral faith. After the war, Rabbi Henri Schilli, who became the director of the rabbinical seminary in Paris in 1950, related how father Braun's principle of solidarity with the Jews dominated the priest's actions during the entire occupation. Thus, dressed in his Jesuit robes, he even participated in services at the Toulouse synagogue in 1942. Father Braun was appointed chaplain of the detention camps of Gurs and Rivesaltes in southern France. Henri Schilli was then the rabbi of those two

(C) BERNAUER, 2018 | DOI 10.1163/22141332-00502006

This is an open access article distributed under the terms of the prevailing CC-BY-NC license at the time of publication. 
camps and he witnessed the actions of the Jesuit. To help the Jewish detainees he worked hand in hand with most of the Jewish relief organizations, with rabbis, and with other Jewish leaders. He also cooperated with Amitié chretienne, an organization founded in Lyons to assist persecuted Jews. In November of that year, when the Germans occupied southern France, Roger Braun opened a branch of Amitié chretienne in Limoges and maintained contact with the Organisation de secours aux enfants, which took care of Jewish children. He did so in cooperation with Protestant organizations and Jewish underground movements. When the persecution of Jews reached its peak in 1942-43, he was in constant contact with the administration of the French rabbinate and with the rabbis in the large cities of the southern zone. Thanks to his networks he was able to help Jewish prisoners and even free some of them. Thus, in September 1942, Father Braun persuaded the commander of the Rivesaltes camp not to deport thirty Jewish children, but rather to entrust them to secours suisse. He also helped get Jewish children transferred to Switzerland and Spain and had Jews hidden in Catholic establishments. He gave refuge to young Jews in a secondary school run by the Jesuits in Toulouse, and thanks to him the students of a rabbinical seminary took refuge in a hiding place in a church in Limoges. He obtained ration cards and forged documents for those whom he protected and continued to associate with Jews openly. When the Germans arrested Rabbi Abraham Deutsch and incarcerated him in Limoges, Father Braun visited him and brought books and tefillin despite the constant danger. Father Braun devoted all his efforts during the occupation period to the rescue of Jews. When the Gestapo, suspecting that he was assisting Jews, had him followed, he went underground. After the war, he continued his activities on behalf of Jews and founded Rencontres judéo-chretiennes, a French movement that promoted Christian-Jewish encounters.

On July 13, 1972, Yad Vashem recognized Father Roger Braun as Righteous among the Nations.

\section{Chaillet, Father Pierre}

Pierre Chaillet, a Jesuit priest in Lyons, mobilized Catholics during the occupation to help camp inmates in southern France. He commented on the inactivity of the Catholic Church: "It pains me to note that everything being done to help prisoners and urban refugees is carried out by Protestant and Jewish organizations." In 1941, Chaillet inaugurated an underground journal called Les Cahiers du témoignage chrétien. The first issue, entitled "France, Beware, Lest You Lose Your Soul," had a press run of five thousand copies. In 1941, four additional 
issues appeared, each twenty pages long as did a second printing of the first number, with thirty thousand copies distributed. Les Cahiers was the only underground journal in France that pointedly condemned anti-Semitism and countered the authorities anti-Semitic propaganda with its own propaganda. This effort, orchestrated by Chaillet, gathered momentum across France and continued until liberation in cooperation with Protestant minister Roland de Pury and others. Chaillet helped found the Amitié chrétienne rescue organization. He also provided Jewish refugees with forged papers, helped smuggle Jews into Switzerland, and in late August 1942, when a group of activists from Amitié chrétienne came to the aid of Jewish rescue organizations, he took part in the rescue of 108 Jewish children from the Venissieux transit camp near Lyons. Chaillet was ordered by the Vichy Interior Ministry to divulge to Cardinal Pierre Marie Gerlier the addresses of the Jewish children's hiding places. When Chaillet refused, the government banished him for two months to a psychiatric hospital in Privas, a town south of Lyons. In February 1943, the Gestapo raided the offices of Amitié chrétienne and arrested all the members there, including Chaillet. He was made to stand facing a wall; while he waited to be interrogated, he swallowed the incriminating documents that were in his pocket. When he finished, Chaillet began to shout, protesting the injustice being done to "a poor village priest, a refugee from the north." He was released but only after receiving a brutal beating. Undeterred, Chaillet continued to campaign for the rescue of Jews in his underground newspaper. Father Chaillet was one of the intellectual leaders of the French Catholic community. In contrast to Cardinal Suhard, head of the Catholic Church in Paris, who declared that illegal actions on behalf of Jews were "grave violations of the precepts of personal and collective ethics," Chaillet argued that "saving an innocent person is not a rebellious act but rather compliance with the oral, unwritten precepts of law and justice."

On July 15, 1981, Yad Vashem recognized Father Pierre Chaillet as Righteous among the Nations.

\section{De Coster, Father Jean-Baptiste}

Father Jean-Baptiste de Coster was a member of the Society of Jesus and headed the College of Saint Jean Berchmans in Brussels. At the request of the Benedykt Grynpas network, he agreed to shelter large groups of Jews in his college. The hidden Jews ran their lives quite independently of the rest of the college. Among them were many young people who were allowed to take part in the classes held in the college, thereby minimizing the damage to their education during the war years. He helped forge baptism certificates and other false 
papers, thereby safeguarding many Jews from deportation. Alexander Blinder and his wife were among the families helped by Father de Coster.

On June 24, 1975, Yad Vashem recognized Father Jean-Baptiste de Coster as Righteous among the Nations.

\section{Fleury, Father Jean}

During the occupation, Father Jean Fleury of Poitiers (Vienne) was active in rescuing persecuted Jews. In his capacity as priest, Fleury paid daily visits to a detention camp for gypsies, which was adjacent, the Route de Limoges camp, where Jews were imprisoned. There, Fleury met his friend, the young rabbi Elie Bloch, who was forbidden to enter the Jews' camp, and the two discussed difficulties. Fleury brought Bloch news from the camp and letters from the internees and supported his efforts to protect the families of Jews with young children or sick people. Father Fleury fearlessly acknowledged his friendship with Rabbi Bloch. In February 1943, after Rabbi Bloch was arrested and deported to Auschwitz with his wife and infant daughter, Fleury energetically assumed his duties and became the sole liaison between the interned Jews and the outside world. He rescued Jewish children from the camp and delivered them to French foster families. Father Fleury used his close relations with the French underground and its extensive network to move the children to the south of France. He provided forged papers and travel passes and, more than once, money and food.

After the war, the Breidick family, Jews who lived in a small village fifty kilometers from Poitiers, testified that, in September 1941, a young woman on a bicycle came and told them that Father Fleury advised them to flee. The woman escorted them to a nearby Catholic school, where they stayed overnight. They then stayed with a peasant family for two weeks, from there they were driven in a small truck to a monastery in Poitiers, where Father Fleury greeted them. Two days later, he supplied false papers and travel passes for a train journey to Lyons, where he had arranged housing for them in a monastery, thereby saving their lives. Fleury's only motive in rescuing Jews was humanitarian. In their testimony, many survivors expressed their gratitude to Father Fleury for his extraordinary rescue and assistance efforts. One survivor wrote, "Father Fleury took action to save anyone in trouble, to the limit of his abilities, irrespective of whether the person was a Jew, gypsy, or a Communist, and he did so while endangering himself. He did this out of love of humanity." Rabbi Joseph Bloch, Rabbi Elie Bloch's father, wrote: "We are eternally grateful to Father Fleury, in our minds, he holds a place among the righteous of humankind." 
After the war, Father Fleury became chairman of coson (Comité des oeuvres sociales de la Résistance) and under its auspices continued to help survivors. Subsequently, the government of France acknowledged Fleury's commendable behavior by making him a Chevalier of the Legion of Honor.

On March 24, 1964, Yad Vashem recognized Father Jean Fleury as Righteous among the Nations.

\section{de Ghantuz Cubbe, Father Raffaele}

In September 1943, the Germans occupied Italy, and the persecution of the Jews intensified. In October 1943, the parents of Mario and Graziano Sonnino, along with the parents of their cousin Marco Pavoncello, decided to find refuge for their children on an estate in the Roman countryside. The owner at first agreed to accept the boys, but then apparently changed his mind and decided to move them elsewhere.

In mid-October, he turned to Father Raffaele de Ghantuz Cubbe, the rector of the Nobile Collegio Mondragone (a Jesuit school in Frascati near Rome), with the request that he accept the three children as students in the school. Father Raffaele acceded to the request, and registered the cousins under false identities. He gave their town of origin as one in southern Italy that had been bombed by the Allies, and was therefore unverifiable. The boys were included in all the activities, and led as normal lives as possible in war-torn Frascati. Only two other teachers knew they were Jewish; no one tried to convert them to the Catholic faith. Father Raffaele also gave temporary shelter at the college to many people during aerial bombardments, including the boys' parents, who were hiding elsewhere. This was despite the many dangers facing the rector, with German troops were stationed in Frascati and some even on the grounds of the college. The three children lived at the school under their aliases until liberation in 1944, when they reverted to using their real names. They continued their studies at the college until 1948.

On February 24, 2010, Yad Vashem recognized Fr. Raffaele de Ghantuz Cubbe as Righteous among the Nations.

\section{Gessler, Father Emile}

Father Emile Gessler was a member of the Society of Jesus in Brussels. As such, he was active in rescuing Jewish children at the request of the Benedykt Grynpas rescue network. Father Gessler and several of his companions forged 
baptism papers as part of their assistance to Jews to avoid their deportation to the camps.

On June 24, 1975, Yad Vashem recognized Father Emile Gessler as Righteous among the Nations.

\section{Janssens, Father Jean-Baptiste}

Father Jean-Baptiste Janssens assisted the Benedykt Grynpas network in Brussels by issuing forged baptism certificates for many Jewish children. As a leading member in the Society of Jesus, he was able to enlist many other clergy to help in this rescue operation. In 1946, Father Janssens became the head of the order in Rome.

On June 24, 1975, Yad Vashem recognized Father Jean-Baptiste Janssens as Righteous among the Nations.

\section{Lambrette, Father Alphonse}

Father Lambrette was a member of the Society of Jesus. Responding to the request of the Benedykt Grynpas rescue network in Brussels, he helped by forging baptism papers for Jewish children, which safeguarded them from deportation.

On June 24, 1975, Yad Vashem recognized Father Alphonse Lambrette as Righteous among the Nations.

\section{Marangos, Father Ioannis}

Gerardo Saias was born in Thessaloniki in 1932. His family had Italian citizenship, and therefore was able to leave in the summer of 1942, when the Germans began to intensify the persecution of the Jews. In the following months, a ghetto was established in Thessaloniki, to be followed in spring 1943 by the deportation of over 43,000 Jews to Auschwitz and the destruction of this ancient Jewish community. The Saias family managed to reach Athens, which at the time was still under Italian rule. The relative safety, however, did not last long-in September 1943, the Germans took control of the entire territory of Greece, and the Saias family were once again in danger. The parents decided it would be safest if they split up. The father was to go into hiding in a village that was under the control of the ELAS resistance movement, the mother found 
shelter with a family, and was searching for a safe haven for her eleven-year-old son. She decided to turn to one of her father's acquaintances, a priest at the Catholic cathedral of St. Dionysus. There, she met Ioannis Marangos, a Jesuit priest, who agreed to hide Gerardo in his house. He promised to return the child to his parents after the war, and only if they did not return, would the child be raised to be a Jesuit.

Gerardo was taken to the Jesuit religious community at 28 Michael Voda Street in Athens and introduced as the priest's nephew. Only Marangos and another brother, Nikolaos Xanthatus, knew that the boy was Jewish. He served as an altar boy, but Father Marangos kept his promise and no attempt whatsoever was made to persuade him to convert. Gerardo stayed in the community for over a year, and had no contact with his family. "As well as being my mother, father and spiritual guide," wrote Gerardo Saias in his testimony, "Father Marangos was also an extremely good teacher. In addition to the religious instruction, which he gave me himself, and the mathematics lessons that Father Philippas gave me, I acquired an extensive general education at his side. The Jesuits are renowned for their wide knowledge."

Following liberation, Gerardo's parents came to take him home. By that time Gerardo was so attached to Father Marangos, that he did not want to leave the community. It was the priest who persuaded him to go with his parents.

Attempting to make their son forget the men religious and their community, his parents never mentioned Marangos, but as Gerardo found out later that they did maintain contact with the man who had saved their son's life. Only when he was older, did his parents permit him to visit Father Marangos. From that time on, the Catholic priest became a family friend, attended all the celebrations, including religious holidays, and Gerardo visited him frequently. When Ioannis Marangos passed away in 1989 at the age of eighty-eight, Gerardo felt as if he had lost his father.

On March 7, 2010 Father Ioannis Marangos was posthumously recognized as Righteous among the Nations.

\section{Planckaert, Father Emile Joseph Marie}

In 1940, Father Emile Planckaert, a French army chaplain, was taken prisoner by the Germans. A year later he escaped his captors and returned to Paris. From 1942 on, Planckaert visited the prisons of Paris, offering solace and spiritual comfort to inmates who opposed the Nazi regime. When he discovered that Cascarne des Tourneles, a barracks converted into a prison, held "criminals" whose only offense was their Jewishness, Planckaert requested permission to visit them as well. Initially, the prison authorities rejected his request, but his 
persistence eventually won them over. Horrified by the living conditions in the prison Planckaert attempted to mobilize the Catholic Church in his struggle to alleviate the Jewish prisoners' plight. During a visit to the prison in Tourelles, Planckaert met a Jewish prisoner named Odette Daltroff. A short time later, Daltroff was sent to the Drancy detention camp, where her mother was already detained. Thanks to M. Baticle, Odette's fiancè both women were released upon their return to Paris, they discovered that the occupation authorities were looking for them. Planckaert provided forged identity cards and found them shelter in the convent of les Soeurs de Saint Régis. Daltroff's mother remained in hiding there until the end of the occupation, but Odette, whose youth was conspicuous among the elderly nuns, needed another hiding place. She moved from one hiding place to another with the arrangements and ration cards organized by Planckaert. By virtue of Planckaert's courage and humanity. Daltroff and her mother were saved. The Daltroffs were not the only beneficiaries of Planckaert's aid. Many other Jews obtained false identity cards from him. In his weekly sermons, Planckaert also gave vent to his views, harshly and boldly condemning the occupation authorities' attitude toward the Jews. In 1943, Planckaert joined Father Théomir Devaux of the order of Notre-Dame de Sion and helped him rescue many Jewish children, Planckaert and Devaux arranged refuge for children whose parents had been arrested by placing them with non-Jewish families.

On April 16, 1972, Yad Vashem recognized Father Emile Joseph Marie Planckaert as Righteous among the Nations.

\section{Raile, Father Jakob}

Father Jakob Raile was a Jesuit priest, who served as the superior of a community located at 52 Maria Street in Budapest. During the Arrow Cross period, the community in which Raile served was used as a hiding place for some 150 Jews. Raile was like a true father to these fugitives, worrying about their safety, and providing for all their needs. In addition to taking care of the Jews hidden in his own monastery, Raile was in contact with the Swedish Red Cross on behalf of the apostolic nuncio in Budapest, as coordinator of rescue activities carried out by groups associated with the Swedish Red Cross. When Arrow Cross gangs attacked, Father Raile stood heroically in the doorway, arguing with the intruders until the Jews inside the monastery had time to hide. On more than one occasion, Raile was forced to let the Arrow Cross men enter the building. He led them from room to room, from the top floor to the basement. At the end of one such search, the Arrow Cross men entered the coal cellar, where Jews were hiding atop a pile of coal, under a dark blanket. Even under these tense circumstances, Father Raile remained calm. He turned out the light and 
quietly announced: "There is only coal here, be careful you don't get dirty." The Arrow Cross men quickly left the basement, without carrying out a thorough search. Army deserters and labor-servicemen who had run away from their units also found refuge in the community. Raile obtained guns and police uniforms for some of the army deserters and had them stand at the religious house's entrance when Arrow Cross intruders approached. They prevented the Arrow Cross men from entering. Raile entered the closed ghetto together with representatives of the Swedish Red Cross, giving food and medicine to ghetto residents. He also distributed blank baptism certificates, with which they could forge documents that would help them to escape from the ghetto. Throughout the battles of Budapest, Raile braved the constant bombing, wandering the city streets looking for food for the Jews he was hiding. Raile died in September 1949 as a result of a traffic accident in the United States.

On September 27, 1991, Yad Vashem recognized Jakob Raile as Righteous among the Nations.

\section{Revol, Father Henri}

Father Henri Revol lived in St.-Gervais-les-Bains, in the département of HauteSavoie. The area's proximity to the Swiss frontier attracted hundreds of Jewish refugees who wished to escape by crossing the border. Many refugees came to Father Revol, who guided them along difficult mountain trails. Among those whom Father Revol smuggled into Switzerland were the Najman family, a couple by the name of Buikovsky, and Mme. Edberg. Revol refused to accept any compensation for his efforts, even a donation to the poor people of his parish. German-born Anni Ebbecke, who, along with her husband was removed from the Guts concentration camp, found temporary shelter with peasants near St. Gervais until Father Revol guided them across the Swiss border near Annemasse. By the summer of 1944, Father Revol was wanted for hiding young men who had evaded conscription for forced labor in Germany. They were arrested and executed by the Germans. Consequently, on August 13, 1944, Revol had to leave the area and go into hiding

On January 24, 1978, Yad Vashem recognized Father Henri Revol as Righteous among the Nations.

\section{Sztark, Father Adam}

Adam Sztark was thirty-two years old when, on the eve of the outbreak of the war, he was appointed as priest of the Catholic community in Żyrowice near 
Słonim (Nowogródek County, today Belarus) and rector of the Jesuit church in Słonim. When the region was occupied by the Germans in the summer of 1941 and they began the murder of the Jews, he came out unequivocally in support of the Jews not only in his sermons from the pulpit, but also in his personal activity. When the Germans demanded a "contribution" on the Jewish community of Słonim, he collected valuables and money from his congregation in order to participate in this tax and thus demonstrated openly his and his flock's solidarity with their persecuted Jewish neighbors. He appealed to his congregation to help the Jews in their distress. He provided "Aryan" papers to Jews in hiding and sent Jewish children to hide with Christian families and in the orphanage. He personally took care to arrange for a Jewish orphan named Jerzy to hide in the home of a Polish gardener, Józef Mikuczyn, and thanks to Adam's efforts, the boy survived. Adam was an exemplary man who worked fearlessly out of his deep religious conviction that it was his duty to help the weak and the persecuted and to rescue people regardless of what ethnicity they were or what beliefs they adhered to. He did not differentiate between Christians and Jews, and for his attitude and work he paid with his life. In December 1942, when the last of the Jews of the Słonim ghetto were exterminated, the Germans also murdered Adam Sztark.

On January 15, 2001, Yad Vashem recognized Adam Sztark as Righteous among the Nations.

\section{Van Oostayen, Father Henri}

Father Henri van Oostayen belonged to the Society of Jesus and served as a chaplain in the Red Cross. He was also part of the Benedykt Grynpas rescue network in Brussels. He was eventually arrested by the Germans, and died in the Bergen-Belsen camp in April 1945.

On June 24, 1975, Yad Vashem recognized Father Henri van Oostayen as Righteous among the Nations. 